\title{
The Contribution of Cyanobacteria Bloom Decline to Phosphorus in Water Column of Dianchi Lake, China
}

\author{
Shenghua Zhang ${ }^{1,2}$, Weilu Wang ${ }^{1,3}$, Junjun Chang1* \\ ${ }^{1}$ School of Ecology and Environmental Science, Yunnan University, Kunming, China \\ ${ }^{2}$ College of Resources and Environmental Science, South-Central University for Nationalities, Wuhan, China \\ ${ }^{3}$ Yunnan Academy of Environmental Science, Kunming, China
}

Received: 23 May 2018

Accepted: 11 August 2018

\begin{abstract}
Bloom-Cyanobacteria can release phosphorus (P) into overlying water during their decline period, thus inevitably providing available $\mathrm{P}$ for the next round of bloom. In order to quantitatively evaluate the contribution of cyanobacterial bloom decline to $\mathrm{P}$ amounts in Caohai, a typical cyanobacteria-dominated sub-lake in northern Dianchi Lake, the $\mathrm{P}$ concentrations in algae during the peak and bottom of cyanobacterial bloom were measured and calculated. Remote sensing monitoring analysis and monthly monitoring data showed that the cyanobacterial bloom in Caohai developed from June, reached its peak in July to August and then declined to its bottom from December to February. The concentrations of different phosphorus forms contained in algal cells were different between the peak and bottom of the cyanobacterial bloom. Total phosphorus (TP) concentration in algae (TP-A) were higher in summer than in winter, while the TP content per unit Chl-a in winter was much larger than in summer. The annual released TP was approximately 24.12 tons in 2016, and its potential contribution to TP and Ortho-P in water body of Caohai was around 0.958 and $0.647 \mathrm{mg} \cdot \mathrm{L}^{-1}$, respectively. The P release amount was 303.30 and 20.57 tons in 2011 and 2014, respectively. For Caohai of Dianchi Lake, the P released from bloom-cyanobacteria could provide adequate P for the next year's bloom recovery.
\end{abstract}

Keywords: eutrophication, cyanobacterial bloom decline, phosphorus release, Dianchi Lake

\section{Introduction}

Excessive nutrients input will cause eutrophication of lakes and it will frequently lead to heavy algal bloom. It is well known that great efforts have been made

*e-mail: changjunjun@ynu.edu.cn to reduce external nitrogen $(\mathrm{N})$ and phosphorus $(\mathrm{P})$ loadings, while some lakes don't respond rapidly to such reductions [1-2]. The reason would be that lake eutrophication is not only associated with excessive external nutrient input, but also connected with unobserved internal nutrient cyclings [3]. Growing evidence has shown that the internal loading of $\mathrm{N}$ and $\mathrm{P}$ in shallow lakes is probably one of the main forces maintaining the eutrophication of lakes and 
preventing the improvement of water quality [2-3]. The internal $\mathrm{N}$ and $\mathrm{P}$ loadings could be equal or even higher to external loadings in summer from the longterm observation of six shallow lakes [4]. Based on these previous studies, the causal processes would be: excessive external nutrient input will lead to the accumulation of internal nutrient loading and increase nutrient concentration in overlying water, and finally algal blooms. For shallow lakes, the internal nutrients accumulation is becoming the most primary driver to induce and support the development of cyanobacterial bloom after the reduction of external loadings [5].

Phosphorus is usually considered the critical limiting element to cyanobacterial bloom and eutrophication [6], and phytoplankton plays a vital role in the biogeochemical cycle of $\mathrm{P}$ in freshwater ecosystems [7-8]. The $\mathrm{P}$ uptake during the development of water bloom and $\mathrm{P}$ release from cyanobacteria during bloom decline are the most important processes involved in the biogeochemical cycle of P [9-10]. Many previous studies have shown that the bloom-cyanobacteria will release $P$ into surrounding water after their decline [11-14]. Chuai et al. [15] reported that cyanobacterial bloom released abundant $\mathrm{P}$ into the overlying water in Taihu Lake. A recent study suggested that cyanobacterial bloom was a driving force for P moving among water, cyanobacteria and sediment [13]. In addition, debris derived from algae and aquatic macrophytes can be sources for internal recycling of $\mathrm{P}$ [16].

The biogeochemical cycle of $\mathrm{P}$ is an important nutrient self-regulating mechanism to sustain eutrophication in eutrophic lakes [16-17], and it can be significantly affected by $\mathrm{P}$ release from bloom-cyanobacteria in the lake area where bloomcyanobacteria is seriously accumulated [15]. There is no doubt that the $\mathrm{P}$ release from cyanobacteria during the bloom decline period would increase the available $\mathrm{P}$ amount in overlying water. Despite the advances on understanding the role of internal $\mathrm{P}$ cycling, the contribution of cyanobacterial bloom decline to $\mathrm{P}$ amount and further to the second algal bloom is still not well understood.

Dianchi Lake $\left(24^{\circ} 40^{\prime}-25^{\circ} 02^{\prime} \mathrm{N}, 102^{\circ} 36^{\prime}-103^{\circ} 40^{\prime} \mathrm{E}\right)$ is the largest plateau lake in Yunnan Province (southwestern China), and it has not recovered from severe eutrophication status [18]. It remains one of most serious cases of freshwater lake eutrophication in China, and cyanobacterial blooms have occurred across the whole lake annually. Caohai, located in northern Dianchi Lake, is a typical cyanobacteria-dominated lake region [19]. The objective of this work is to evaluate the contribution of cyanobacteria bloom decline to $\mathrm{P}$ content and the amount in Caohai of Dianchi Lake, China. The amount of phosphorus contained in the algae will vary with their growth status, and may lead to seasonal differences. Therefore, the seasonal characteristic of cyanobacterial bloom was verified and the $\mathrm{P}$ concentrations in algae during the peak and bottom of cyanobacterial bloom were measured and calculated.

\section{Materials and Methods}

\section{Study Sites and Sampling}

The peak of cyanobacterial blooms in Dianchi Lake is usually observed during July to August, and the bloom is declined during December to January [20]. To investigate the $\mathrm{P}$ concentration in bloom-cyanobacteria in Caohai and calculate the released $\mathrm{P}$ amount, water and algae samples were collected twice: once in summer (August 21, 2016) and another in winter (January 9, 2017). The specific sampling date was set according to the peak and bottom of cyanobacterial bloom, as well as weather conditions and satellite transit date. The detailed locations of the 30 sampling sites in Caohai are presented in Fig.1.

Integrated samples containing water and algae were collected approximately $0.5 \mathrm{~m}$ below the water surface, and then kept in a portable refrigerator and delivered to the laboratory. They were stored at $0-4^{\circ} \mathrm{C}$, and analyzed within $48 \mathrm{~h}$. The temperature, $\mathrm{pH}$, electrical conductivity (EC) and oxidation reduction potential (ORP) of the overlying water were detected at $0.5 \mathrm{~m}$ depth in situ using a multi-parameter water quality instrument (HORIBA U51-10).

\section{Measurements and Calculation}

The contents of several $\mathrm{P}$ forms in integrated water samples were determined, including total P (TP) in integrated water sample, dissolved TP in water (TP-W), TP in algae (TP-A), dissolved orthophosphate in water (Ortho-P-W), and orthophosphate in algal cell (Ortho$\mathrm{P}-\mathrm{A})$. The TP in integrated water sample includes two

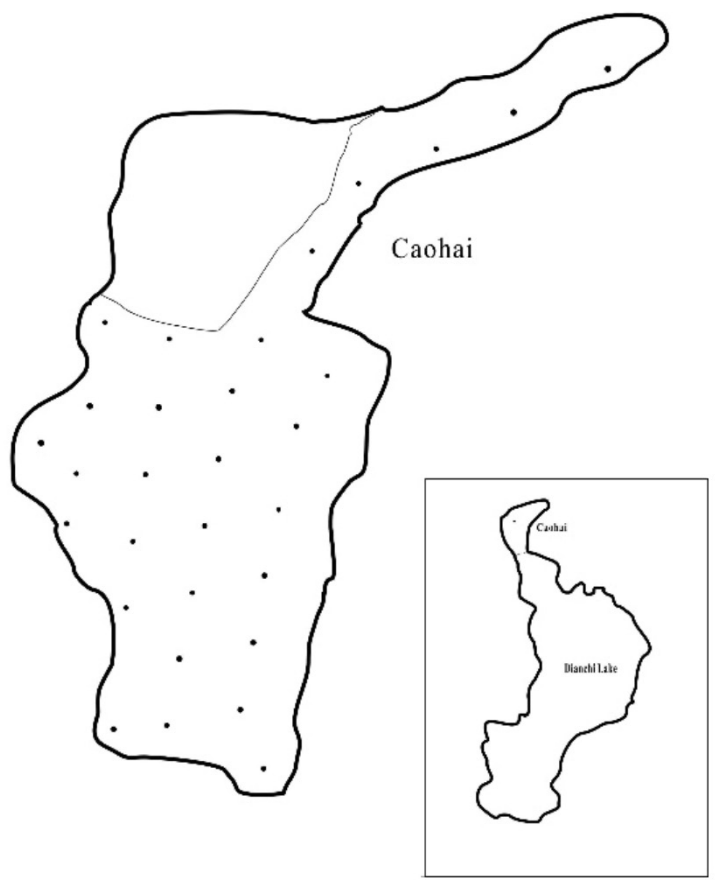

Fig. 1. Sample distribution map in Caohai, Dianchi Lake, China. 
parts, TP-W and TP-A. TP-A can be further divided into ortho-P-A and other $\mathrm{P}$ forms (other-P-A). The other-P-A mainly refers to organic $\mathrm{P}$ (OP-A) and polyphosphate particles (Poly-P-A) in algae. The content of other-P-A was calculated through subtracting ortho$\mathrm{P}-\mathrm{A}$ from TP-A. The relationships of different $\mathrm{P}$ forms are depicted in the following equations:

$\mathrm{TP}$ in integrated water samples $=$ $\mathrm{TP}$ in water (TP-W) + TP in algae (TP-A)

$$
\text { TP-A }=\text { Ortho-P-A + OP-A + Poly-P-A in algae }
$$

Some of the integrated samples were filtered through a $0.45 \mu \mathrm{m}$ membrane to separate water and algae. The contents of TP-W and ortho-P-W in water samples, and the contents of chlorophyll a (Chl-a), TP-A and ortho-P-A in algae samples were determined. The Chl-a concentration was measured using the colorimetric method [21]. Ortho-P-W was detected using the molybdenum blue colorimetric method [21]. TP of integrated sample TP-W and TP-A were analyzed using the molybdenum blue colorimetric method after digestion with $\mathrm{K}_{2} \mathrm{~S}_{2} \mathrm{O}_{8}$ to orthophosphate [21]. The Ortho-P-A was measured according to Shi et al. [22].

The P amount per mg Chl-a was obtained through dividing $\mathrm{P}$ concentration by $\mathrm{Chl}-\mathrm{a}$ concentration in the algae. The total $\mathrm{P}$ concentration was calculated through multiplying the average $\mathrm{Chl}-\mathrm{a}$ concentration by the $\mathrm{P}$ amount per unit of Chl-a. Caohai has an area of $10.8 \mathrm{~km}^{2}$ with an average depth of $3.0 \mathrm{~m}$ and water storage capacity of 25.17 million $\mathrm{m}^{3}$. According to the seasonal fluctuation of cyanobacterial bloom, the $\mathrm{P}$ contribution of bloom-cyanobacteria can be estimated through the subtraction of P-A between the peak a nd bottom of the cyanobacterial bloom. The total P amount released by bloom-cyanobacteria could be estimated through multiplying TP concentration by water volume.

\section{Extraction of Chlorophyll a Concentration}

Remote sensing monitoring of water quality parameters can better reflect the spatial and temporal distribution and changes of regional water qualities, and is particularly suitable for the rapid monitoring of a wide-ranging water region [23]. In this study, Caohai was studied based on CCD1 data of HJ-1A satellite according to an algorithm developed by Yang et al. [24], in which the best band combination (b4-b3)/(b4+b3) is used as an indicator for Chl-a concentration in Dianchi Lake. The b3 and b4 refers to the data in the $3^{\text {rd }}$ and $4^{\text {th }}$ band of CCD1 data of HJ-1A satellite. The inversion model of Chl-a content in Dianchi was $\mathrm{y}=-114.25 x^{2}+304.80 x-2.2149\left(x=\frac{b 4-b 3}{b 4+b 3}, r=0.771\right)$.
In addition, monthly Chl-a data during 2011 was cited from Zhou [25], and those from 2013 to 2016 were collected from routine monitoring program conducted by Kunming Environmental Monitoring Center (unpublished data).

\section{Results and Discussion}

Temporal and Spatial Distribution of Cyanobacterial Blooms in Caohai of Dianchi Lake

The Chl-a concentration is an important index to judge eutrophication status of water bodies, and it can generally reflect the intensity of water bloom. In this study, the Chl-a distribution in Caohai of Dianchi Lake was studied by using remote sensing monitoring method, which was based on CCD1 data of HJ-1A satellite. Due to the complicated plateau climate, it is not possible to obtain a complete monthly satellite image for a whole year. Therefore, some valid representative satellite images during the period from 2009 to 2016 were selected for the extraction of Chl-a contents to show the seasonal development and decline of cyanobacteria bloom. Some monthly dynamic changes of the Chl-a concentration distribution were described in Fig. 2, and the results showed that the cyanobacterial blooms were developed in June, and declined at the end of October. These are in accordance with the previous monitoring results [26]. Based on MODIS satellite remote sensing data, Xie et al. [26] and Jiang [20] revealed that the critical period of cyanobacterial bloom in Dianchi Lake was from June to September. The cyanobacterial bloom has the obvious characteristic of seasonal variation.

High wind speed can agitate the water surface to interfere with the uplift and aggregation of cyanobacteria, resulting in the even distribution of cyanobacteria in water [20]. In summer, the highest and lowest value of Chl-a concentration among 30 sampling sites was determined to be $4441 \mu \mathrm{g} \cdot \mathrm{L}^{-1}$ and $66.40 \mu \mathrm{g} \cdot \mathrm{L}^{-1}$, respectively, and the average value was $637.1 \mu \mathrm{g} \cdot \mathrm{L}^{-1}$. In winter, the Chl-a concentration ranged from 1.905 to $23.70 \mu \mathrm{g} \cdot \mathrm{L}^{-1}$ with an average value of $10.20 \mu \mathrm{g} \cdot \mathrm{L}^{-1}$. This indicated that the cell density of cyanobacteria was much higher in summer than in winter, and apparent seasonal variation of cyanobacterial bloom was observed, which confirmed the developing and declining cyanobacterial bloom annually.

According to the historical monitoring results of Chl-a, the first occurrence of cyanobacterial bloom in Dianchi Lake was observed in 2001, and from then on, harmful cyanobacteria blooms occurred almost every year $[19,27]$. From both the intensity and frequency of algal bloom, the cyanobacterial bloom in Dianchi Lake presented annual cyclical changes, which is at a low level at spring, increases to high level in the middle of the year, and then declines in the winter [26]. Based on the history data collected by Kunming Environmental Monitoring Center (unpublished data), 


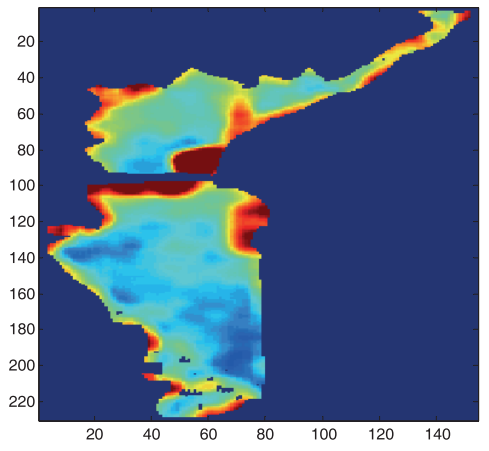

a) May

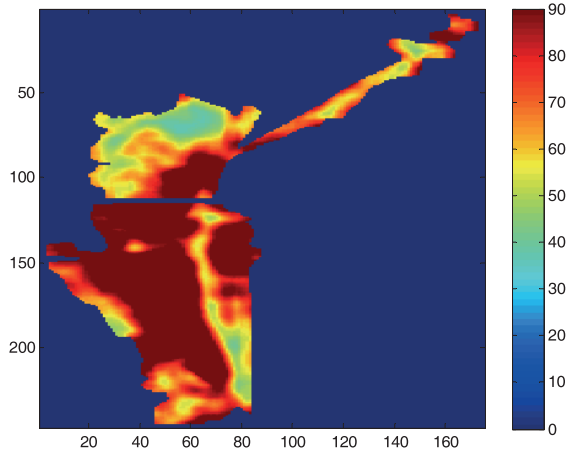

c) August

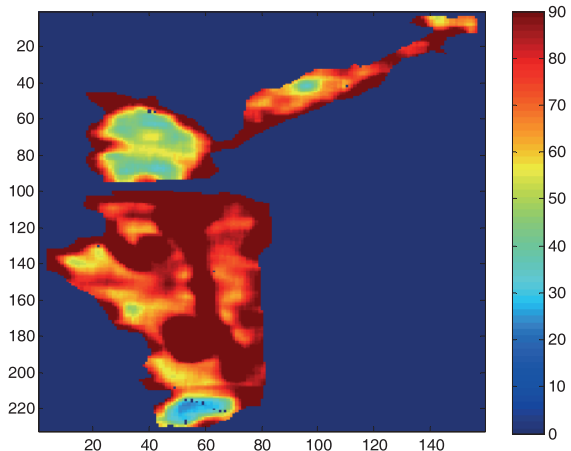

e) October

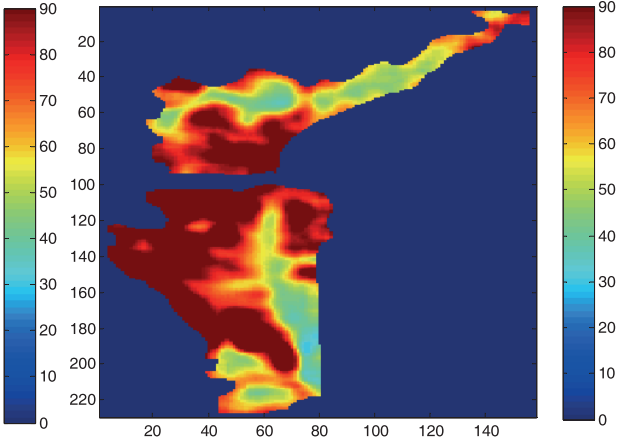

b) June

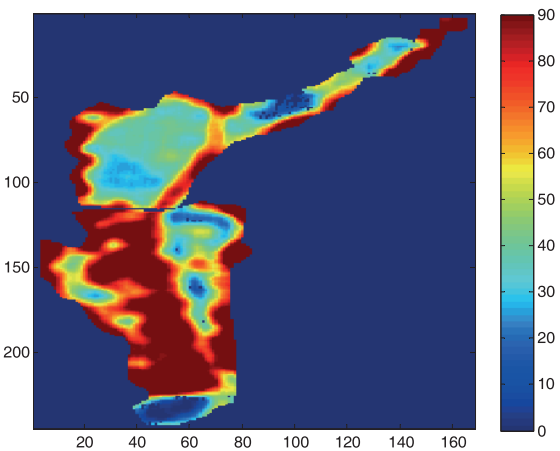

d) September

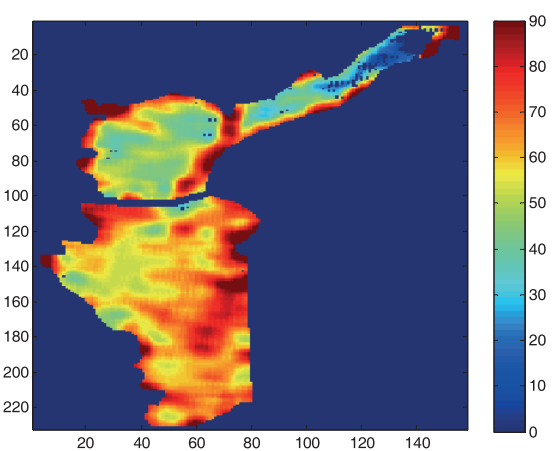

f) November

Fig. 2. Chl-a distributions in different seasons in Caohai of Dianchi Lake (date: a) 20140513, b) 20130616, c) 20130815, d) 20090928, e) 20121020, f) 20151124).

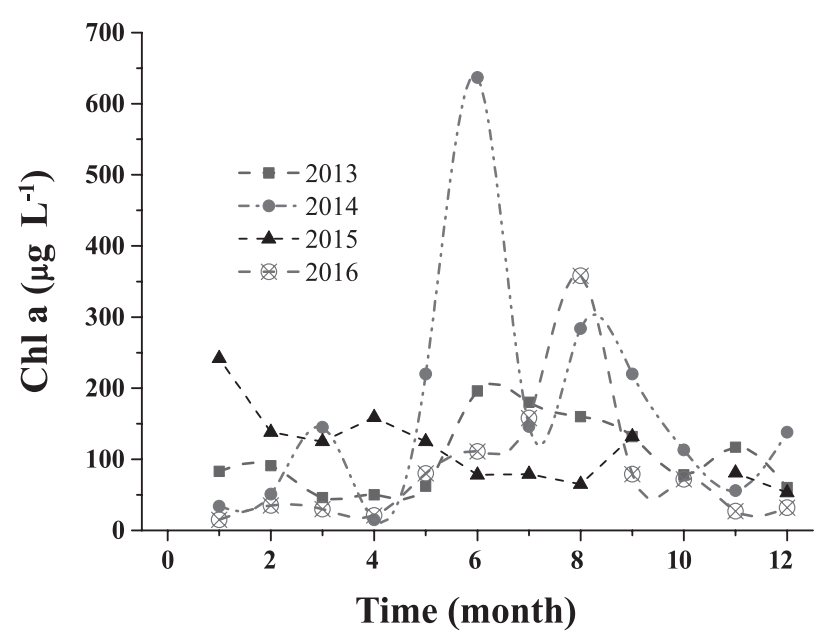

Fig. 3. Annual Chl-a contents in Caohai, 2013-2016.

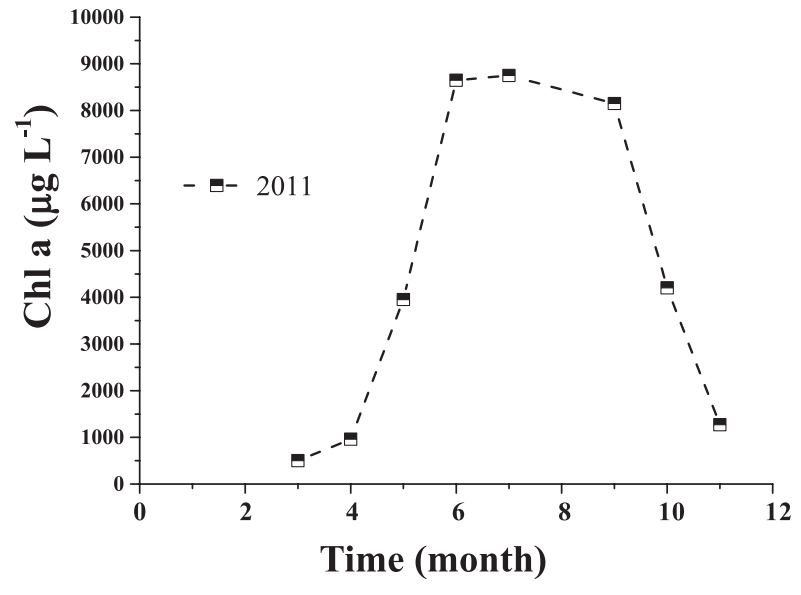

Fig. 4. Variation of Chl-a concentration in total Dianchi Lake during 2011 (cited from Zhou [25], p. 34). 
Table 1. Mean values of physico-chemical parameters of the water body and P contents in bloom-cyanobacteria for the two sample collections (30 sampling points, range in the parentheses).

\begin{tabular}{|c|c|c|}
\hline Items & Summer (21 $1^{\text {st }}$, August, 2016) & Winter (9 $9^{\text {th }}$, January, 2017) \\
\hline Chl-a $\left(\mu \mathrm{g}-\mathrm{L}^{-1}\right)$ & $637.1(4441-66.40)$ & $10.20(23.70-1.905)$ \\
\hline $\mathrm{TP}\left(\mathrm{mg}-\mathrm{L}^{-1}\right)$ & $0.932(6.459-0.141)$ & $0.0909(0.165-0.0443)$ \\
\hline $\mathrm{TP}-\mathrm{W}\left(\mathrm{mg}-\mathrm{L}^{-1}\right)$ & $0.0374(0.0563-0.0161)$ & $0.0277(0.105-0.004)$ \\
\hline Ortho-P-W (mg-L-1) & $0.0099(0.0362-0.0040)$ & $0.0202(0.105-0.0020)$ \\
\hline TP-A $\left(m g-L^{-1}\right)$ & $0.762(5.905-0.101)$ & $0.0343(0.0652-0.0149)$ \\
\hline Ortho-P-A (mg-L $\left.{ }^{-1}\right)$ & $0.334(1.457-0.0885)$ & $0.0085(0.0185-0.0001)$ \\
\hline $\mathrm{EC}\left(\mu \mathrm{S}-\mathrm{cm}^{-1}\right)$ & $365.9(438-326)$ & $408.3(472-348)$ \\
\hline $\mathrm{pH}$ & $9.328(9.942-8.63)$ & $9.402(9.586-9.179)$ \\
\hline ORP (mv) & $71.30(105.4-42.8)$ & $89.88(118-51.7)$ \\
\hline Temperature $\left({ }^{\circ} \mathrm{C}\right)$ & $24.22(26.2-24)$ & $12.81(13.8-11.9)$ \\
\hline
\end{tabular}

the annual Chl-a concentrations in Caohai between 2013-2016 are shown in Fig. 3, and the monthly Chl-a contents in total Dianchi Lake during 2011 are shown in Fig. 4. These results also confirm the seasonal variation of cyanobacterial bloom.

\section{Phosphorus Concentrations in Algal Cells} in Summer and Winter

To assess the available $\mathrm{P}$ released by bloomcyanobacteria to water, both the average Chl-a and $\mathrm{P}$ concentrations in algal cells ( $\mathrm{P}$ per unit Chl-a) were determined during the peak and bottom of cyanobacterial bloom. The average values and ranges of water quality parameters and $\mathrm{P}$ concentrations in bloomcyanobacteria in the 30 sampling sites during summer and winter were listed in Table 1. As for water quality parameters, except for temperature, the average values of $\mathrm{EC}$, ORP and $\mathrm{pH}$ were little higher in winter than those in summer. A few studies showed the increment of $\mathrm{EC}$ and $\mathrm{pH}$ during the cyanobacterial bloom decline period $[15,18]$, and it has been reported that the ORP was decreased due to the oxygen consumption by decomposition of bloom-cyanobacteria [28]. In this field study, the average value of ORP in winter is a little higher, which would probably be caused by the high speed of wind in winter-enriching oxygen in water [19].
The average TP and TP-A content was $0.932 \mathrm{mg} \cdot \mathrm{L}^{-1}$ and $0.762 \mathrm{mg} \cdot \mathrm{L}^{-1}$, respectively, in summer, while 0.0909 and 0.0343 in winter (Table 1). The TP and TP-A were significantly higher in summer than those in winter, which is consistent with previous studies [18, 29]. In addition, the Ortho-P-W accounted for $26.53 \%$ of TP-W in summer, while reaching $72.90 \%$ in winter. The concentration of dissolved inorganic $\mathrm{P}$ in summer was lower than that in winter, which might be related to the large absorption of inorganic $\mathrm{P}$ by algae during the bloom development period. Through Pearson correlation analysis, the Chl-a concentration was significantly correlated with the TP and TP-A concentrations, and the higher TP in summer mainly resulted from the large amount of algae. The number of algae in winter is small, thus its contribution to total phosphorus in water is correspondingly lower. This result was consistent with the view of Xie et al. [29], stating that low N:P is the result of cyanobacteria bloom rather than the reason. It has been reported that Ortho-P is the main component of total dissolved $\mathrm{P}$ in water during the cyanobacterial bloom decline period [11]. Cao et al. [13] also observed that ortho-P in water increased after the cyanobacteria began to decline. In the present study, the ortho-P-A reached about $43.77 \%$ of TP-A in summer, while it only accounted for $24.63 \%$ of TP-A in winter. This might suggest that the ortho-P was released from bloomcyanobacteria during their decline period [12]. Large

Table 2. The P contents per unit Chl-a during the summer and winter (mean \pm standard deviation, 30 sampling points).

\begin{tabular}{|c|c|c|}
\hline \multirow{2}{*}{ Item } & \multicolumn{2}{|c|}{ Concentration in algae (mg/mg Chl-a) } \\
\cline { 2 - 3 } & Summer & Winter \\
\hline TP & $1.554 \pm 0.579$ & $3.080 \pm 1.439$ \\
\hline Ortho-P & $1.031 \pm 0.535$ & $0.929 \pm 0.557$ \\
\hline Other P (OP and Poly-P) & $0.523 \pm 0.416$ & $2.151 \pm 1.160$ \\
\hline
\end{tabular}


Table 3. P release amounts from bloom-cyanobacteria based on our sampling determination.

\begin{tabular}{|c|c|c|c|}
\hline Items & Summer & Winter & $\Delta \mathrm{P}$ \\
\hline TP-A $\left(\mathrm{mg}-\mathrm{L}^{-1}\right)$ & $0.990 \pm 0.369$ & $0.0314 \pm 0.0147$ & 0.959 \\
\hline Ortho-P-A $\left(\mathrm{mg}^{-1}\right)$ & $0.656 \pm 0.341$ & $0.0095 \pm 0.0057$ & 0.647 \\
\hline Other P-A (mg-L $\left.{ }^{-1}\right)$ & $0.334 \pm 0.265$ & $0.0219 \pm 0.0118$ & 24.12 \\
\hline TP-A (ton) & 24.91 & 0.791 & 16.28 \\
\hline Ortho-P-A (ton) & 16.52 & 0.239 & 7.838 \\
\hline Other P-A (ton) & 8.39 & 0.552 & \\
\hline
\end{tabular}

amounts of $\mathrm{P}$ will be released into the surrounding water during cyanobacterial bloom decline period [15], which would certainly affect the $\mathrm{P}$ adsorption equilibrium between the sediment and overlying water. On the one hand, due to the decomposition of bloom-cyanobacteria, the DO and ORP of water would decrease, promoting P release from the sediment [18-19]. On the other hand, the large amount of $\mathrm{P}$ released from bloom-cyanobacteria will gradually settle into the sediment. In this study, the ORP in algal bloom decline period was higher than that in bloom development period (Table 1). The higher ORP will prevent the release of $\mathrm{P}$ from sediment and stimulate the entry of $\mathrm{P}$ in overlying water into the sediment. This will probably provide a good explanation on the lower $\mathrm{P}$ content dissolved in water (Table 1) at the end of the cyanobacterial bloom decline period.

The $\mathrm{P}$ amount per mg Chl-a could be obtained through dividing $\mathrm{P}$ concentration by $\mathrm{Chl}-\mathrm{a}$ concentration in the algae. The TP in algae includes ortho-P, OP and polyphosphate particles (poly $\mathrm{P}$ ). By calculation, the contents of TP, ortho-P and other P (OP and poly $\mathrm{P}$ ) in algae per mg Chl-a during summer and winter are listed in Table 2. As for the average results of the Caohai region, the TP per unit Chl-a in winter was much larger than that in summer, but the ortho-P per unit Chl-a in winter is slightly less than that in summer. The main $\mathrm{P}$ form contained in algae is ortho- $\mathrm{P}$ during summer, which accounted for $66.30 \%$ of TP. In contrast, the OP and Poly-P per unit Chl-a took up $69.84 \%$ of TP in algae in winter.

\section{Estimating P Amount Released from Bloom-Cyanobacteria in Caohai}

Based on our two sampling campaigns, the $\mathrm{P}$ amounts released from bloom-cyanobacteria in Caohai are shown in Table 3. The $\mathrm{P}$ amount contained in bloom-cyanobacteria in summer was 24.91 tons in 2016, and was just 0.79 tons in winter. The released TP from bloom-cyanobacteria was about 24.12 tons, including 16.28 tons of ortho-P and 7.84 tons of other-P (OP and poly $\mathrm{P}$ ). The potential contribution of TP, ortho-P and other-P from bloom-cyanobacteria to the $\mathrm{P}$ concentration in water of Caohai for the next round of cyanobacterial bloom was about $0.959,0.647$ and $0.312 \mathrm{mg} \cdot \mathrm{L}^{-1}$, respectively.

Combined with the average Chl-a concentrations, which were provided by Kunming environmental monitoring station and cited from relevant references, and $\mathrm{P}$ amount per mg Chl-a (Table 2), the $\mathrm{P}$ release amounts in the year 2011 and 2014 were estimated. The contributions of $\mathrm{P}$ release from bloom-cyanobacteria to the $\mathrm{P}$ concentration and amount in Caohai water body were shown in Table 4. The $\mathrm{P}$ release amount from bloom-cyanobacteria was 20.57 tons in 2014, and the concentration of $\mathrm{P}$ reached $0.817 \mathrm{mg} \cdot \mathrm{L}^{-1}$. Based on the Chl-a data cited from Zhou [25], the released P amount was 303.30 tons during cyanobacterial bloom decline period in 2011, leading to a $\mathrm{P}$ concentration increment of $12.05 \mathrm{mg} \cdot \mathrm{L}^{-1}$ in Caohai.

Table 4. Estimations of P release amounts in 2011 and 2014.

\begin{tabular}{|c|c|c|c|c|c|}
\hline Items & Summer & Winter & Items & $\Delta \mathrm{P}\left(\mathrm{mg}-\mathrm{L}^{-1}\right)$ & $\Delta \mathrm{P}($ ton $)$ \\
\hline \multicolumn{6}{|c|}{2011} \\
\hline TP-A (mg-L-1 $)$ & $13.591 \pm 5.062$ & $1.540 \pm 0.719$ & $\mathrm{TP}$ & 12.05 & 303.30 \\
\hline Ortho-P-A (mg-L-1) & $9.013 \pm 4.680$ & $0.464 \pm 0.278$ & Ortho-P & 8.549 & 215.18 \\
\hline \multicolumn{6}{|c|}{2014} \\
\hline TP-A $\left(m g-L^{-1}\right)$ & $0.990 \pm 0.369$ & $0.173 \pm 0.0806$ & $\mathrm{TP}$ & 0.817 & 20.57 \\
\hline Ortho-P-A (mg-L-1) & $0.656 \pm 0.341$ & $0.0520 \pm 0.0312$ & Ortho-P & 0.604 & 15.20 \\
\hline
\end{tabular}

(The average Chl-a contents in Caohai during 2014 were provided by Kunming environmental monitoring station; The average

Chl-a contents in Caohai during 2011 were cited from Zhou [25], pp34) 
The occurrence of annual cyanobacterial bloom requires a lot of nutrient supplement. As for Dianchi Lake, internal cycling decides the nutrient limitation [3], and the $\mathrm{P}$ in sediments represented a significant supply for the growth of cyanobacteria [13]. Ortho-P is the only $\mathrm{P}$ form that can be utilized directly by algae. A recent study showed that the organic $\mathrm{P}$ was less likely to cause $M$. aeruginosa bloom, and the utilization of organic $\mathrm{P}$ by algae was highly dependent on its transformation into Ortho-P [14]. In this study, we evaluated the contribution of decline cyanobacterial bloom to the $\mathrm{P}$ amount in Caohai of Dianchi Lake and revealed that the amount of TP and Ortho-P released from cyanobacterial bloom could provide adequate $\mathrm{P}$ to water body for the next year's algal bloom recovery in Caohai. If the external pollution loadings of Dianchi Lake could be reduced to a much low level, the $\mathrm{P}$ release from cyanobacterial blooms that have taken place would also be able to provide sufficient $\mathrm{P}$ to meet the $\mathrm{P}$ demand for the new round of cyanobacterial bloom. This kind of $\mathrm{P}$ internal cycling would probably be one of the selfsustaining mechanisms of cyanobacterial bloom and eutrophication. Thus, developing measures to cut off the internal $\mathrm{P}$ cycle driven by cyanobacterial bloom would be necessary for algal bloom control.

\section{Conclusions}

The cyanobacterial bloom in Caohai of Dianchi Lake presented annual cyclical changes. It developed in June, reached peak in July to August and then declined to bottom during December to February of the next year. The concentrations of different phosphorus forms contained in algal cells were different between the peak and bottom of cyanobacterial bloom. The TP and TP-A were higher in summer than those in winter. The TP amount per unit Chl-a in winter was much larger than that in summer, but the ortho-P per unit Chl-a in winter was slightly less than that in summer. The ortho-P per mg Chl-a was about $66.30 \%$ of TP during summer, while the OP and poly-P per mg Chl-a accounted for $69.84 \%$ of TP in winter. Based on our two sample collections in 2016, the released TP from bloom-cyanobacteria was about 24.12 tons, including 16.28 tons of ortho-P and 7.84 tons of other-P (OP and poly $\mathrm{P}$ ). The potential contribution of TP, ortho-P and other $\mathrm{P}$ to $\mathrm{P}$ content in the water of Caohai for the next round of cyanobacterial bloom was about $0.959,0.647$ and $0.312 \mathrm{mg} \cdot \mathrm{L}^{-1}$, respectively. The $\mathrm{P}$ release amount from bloom-cyanobacteria was 303.30 and 20.57 tons in 2011 and 2014, respectively, and the contribution to $\mathrm{P}$ concentration reached 12.05 and $0.817 \mathrm{mg} \cdot \mathrm{L}^{-1}$, respectively. The $\mathrm{P}$ released from bloom-cyanobacteria could contribute a certain amount of TP and ortho-P to the water body and provide adequate $\mathrm{P}$ for next year's algal bloom recovery in Caohai.

\section{Acknowledgements}

This work was financially supported by the National Natural Science Foundation of China (51468066) and the Fundamental Research Funds for the Central Universities, South-Central University for Nationalities (CZY17017).

\section{Conflict of Interest}

The authors declare no conflict of interest.

\section{References}

1. CARPENTER S.R. Eutrophication of aquatic ecosystems: bistability and soil phosphorus. P. Natl. Acad. Sci. USA. 102, 1002, 2005.

2. JEPPESEN E., SONDERGAA D.M., JENSEN J.P., HAVENS K.E., ANNEVILLE O., CARVALHO L., COVENEY M.F., DENEKE R., DOKULIL M.T., FOY B.O.B., GERDEAUX D., HAMPTON S.E., HILT S., KANGUR K., KOHLER J.A.N., LAMMNES E.H.H.R., LAURIDSEN T.L., MANCA M., MIRACLE M.R., MOSS B., NOGES P., PRESSON G., PHILLIPS G., PORTIELJE R.O.B., ROMO S., SCHELSKE C.L., STRAILE D., TATRAI I., WILLEN E.V.A., WINDER M. Lake responses to reduced nutrient loading - an analysis of contemporary long-term data from 35 case studies. Freshw. Biol. 50, 1747, 2005.

3. WU Z., LIU Y., LIANG Z., WU S.F., GUO H.C. Internal cycling, not external loading, decides the nutrient limitation in eutrophic lake: A dynamic model with temporal Bayesian. Water Res. 116, 231, 2017.

4. SONDERGAARD M., BJERRING R., JEPPESEN E. Persistent internal phosphorus loading during summer in shallow eutrophic lakes. Hydrobiologia 10, 95, 2013.

5. NI Z., WANG S., WANG Y. Characteristics of bioavailable organic phosphorus in sediment and its contribution to lake eutrophication in China. Environ. Pollut. 219, 537, 2016.

6. HUANG J., GAO J., YAN R. A phosphorus dynamic model for low land polder systems. Ecol. Eng. 88, 242, 2016.

7. HECKY R.E., KILHAM P. Nutrient limitation of phytoplankton in freshwater and marine environments: a review of recent evidence on the effects of enrichment. Limnol. Oceanogr. 33, 796, 1988.

8. MONBET P., MCKELVIE I., SAEFUMILLAH A. A protocol to assess the enzymatic release of dissolved organic phosphorus species in waters under environmentally relevant conditions. Environ. Sci. Technol. 41, 7479, 2007.

9. SOLIDORO C., PENCENIK G., PASTRES R., FRANCO D., DEJAK C. Modelling macroalgae (Ulva rigida) in the Venice lagoon: model structure identification and first parameters estimation. Ecol. Model. 94, 191, 1997.

10. RODRIGUES M., OLIVEIRA A., QUEIROGA H., FORTUNATO A.B., ZHANG Y.J. Three-dimensional modeling of the lower trophic levels in the Ria de Averio (Portugal). Ecol. Model. 220, 1274, 2009.

11. CHEN W.M., CAI H.J. Study on the aerobic decomposition of Microcystis in Taihu Lake. J. Lake Sci. 8, 248, 1996 [In Chinese]. 
12. ZENG S., YUAN X., SHI X., QIU Y. Effect of inoculum/ substrate ratio on methane yield and orthophosphate release from anaerobic digestion of Microcystis spp. J. Hazard. Mater. 178, 89, 2010.

13. CAO X., WANG Y.Q., HE J., LUO X., ZHENG Z. Phosphorus mobility among sediments, water and cyanobacteria enhanced by cyanobacteria blooms in eutrophic Lake Dianchi. Environ. Pollut. 219, 580, 2016.

14. LIU J.Z., LUO X.X., ZHANG N.M., WU Y. Phosphorus released from sediment of Dianchi lake and its effect on growth of Microcystis aeruginosa. Environ. Sci. Pollut. Res. 23, 16321, 2016.

15. CHUAI X., DING W., CHEN X., WANG X., MIAO A., XI B., HE L., YANG L. Phosphorus release from cyanobacterial blooms in Meiliang Bay of Lake Taihu, China. Ecol. Eng. 37, 842, 2011.

16. FENG W., ZHU Y., WU F., MENG W., GIESY J.P., HE Z., SONG L., FAN M. Characterization of phosphorus forms in lake macrophytes and algae by solution ${ }^{31} \mathrm{P}$ nuclear magnetic resonance spectroscopy. Environ. Sci. Pollut. Res. 23, 7288, 2016.

17. ZHU Y., WU F., HE Z., GUO J., QU X., XIE F., GIESY J.P., Liao H, Guo F. Characterization of organic phosphorus in lake sediments by sequential fractionation and enzymatic hydrolysis. Environ. Sci. Technol. 47, 7679, 2013.

18. ZHANG R., WANG L., WU F. Phosphorus speciation in surface sediments of a hypertrophic lake, Southwestern China: insights from fractionation and ${ }^{31} \mathrm{P}$ NMR. Chin. J. Geochem. 34, 167, 2015a.

19. HU J., SHEN Q., LIU Y.D., LIU J. Mobility of different phosphorus pools in the sediment of Dianchi Lake during cyanobacterial blooms. Environ. Monit. Assess. 132, 141, 2007.

20. JIANG D.L. Research on temporal and spatial variation of algae blooms and its driving factors in Lake Dianchi based on GIS/RS. Master Thesis, Southwest University, Chongqing, China, 2015 [In Chinese].
21. State Environmental Protection Administration of China (SEPA). Monitor and analysis method of water and wastewater, $4^{\text {rd }}$ ed. Chinese Environmental Science Press, Beijing, China, 2002 [In Chinese].

22. SHI X., YANG L., NIU X., XIAO L., KONG Z., QIN M., GAO G. Intracellular phosphorus metabolism of Microcystis aeruginosa under various redox potential in darkness. Microbiol. Res. 158, 345, 2003.

23. VANHELLEMONT Q., RUDDICK K. Advantages of high quality SWIR bands for ocean colour processing: Examples from Landsat-8. Remote Sens. Environ. 161, 89, 2015.

24. YANG R., YANG K., HONG L., YANG Y. A study of inversion modeling of water quality parameters in Dianchi Using HJ-1A CCD1 data. Water Saving Irrigation 3, 42, 2015 [In Chinese].

25. ZHOU M.X. The research on the vernalization in Microcystis aeruginosa in Dianchi Lake. Master Thesis, Chongqing University, Chongqing, China, 2014 [In Chinese].

26. XIE G., LI M., LU W., ZHOU W., YU L., LI F., YANG S. Spectral features, remote sensing identification and breaking-out meteorological conditions of algal bloom in Lake Dianchi. J. Lake Sci. 22, 327, 2010 [In Chinese].

27. HUANG C., WANG X., YANG H., LI Y., WANG Y., CHEN X., XU L. Satellite data regarding the eutrophication response to human activities in the plateau lake Dianchi in China from 1974 to 2009. Sci. Total Environ. 485-486, 1, 2014.

28. ZHANG Z., WANG H., ZHOU J. Redox potential and microbial functional gene diversity in wetland sediments under simulated warming conditions: implications for phosphorus mobilization. Hydrobiologia. 743, 221, 2015b.

29. XIE L., XIE P., LI S. The low TN:TP ratio, a cause or a result of Microcystis blooms? Water Res. 37, 2073, 2003. 